\title{
THE EFFECT OF TAPPING THERAPY ON BLOOD GLUCOSE LEVELS IN TYPE 2 DIABETES MELLITUS PATIENTS AT PURWOKERTO
}

\author{
(Pengaruh Tapping Therapy terhadap Kadar Glukosa Darah pada \\ Pasien Diabetes Mellitus Tipe 2 di Purwokerto)
}

\author{
Atyanti Isworo*, Wahyu Ekowati** \\ * Medical Surgical Department School of Nursing, Medicine and Health Sciences \\ ** Mental Health Department School of Nursing, Medicine and Health Sciences \\ Jenderal Soedirman Univesity, Purwokerto, Central Java, Indonesia \\ Email: attiya fik@yahoo.com, aiko_wati@yahoo.co.id
}

\begin{abstract}
ABSTRAK
Pendahuluan: Diabetes Mellitus (DM) adalah penyakit metabolik kronik yang dapat menyebabkan komplikasi mikrovaskuler dan makrovaskuler. Kondisi ini membuat pasien DM memiliki risiko tinggi mengalami stres. Tapping therapy adalah salah satu intervensi keperawatan yang dapat menurunkan stres. Tujuan dari penelitian ini adalah mengidentifikasi efek tapping therapy pada kadar glukosa darah di Primary Health Center Purwokerto Selatan. Methods: Penelitian ini adalah penelitian kuantitatif dengan kuasi eksperimen dengan kelompok kontrol, diambil 30 responden, terdiri dari 15 responden yang dilatih terapi bekam, satu kali sehari selama 30 menit selama 4 minggu dan responden sisanya adalah sebagai kelompok kontrol. Metode pengambilan sampel menggunakan purposive sampling. Uji Wilcoxon digunakan untuk menguji perbedaan kadar glukosa darah antara kelompok perlakuan dan kelompok kontrol. Hasil: Hasil menyatakan bahwa ada perbedaan signifikan kadar glukosa darah sebelum dan setelah dilakukan perlakuan pada kelompok perlakuan $(\mathrm{p}=0,003, \alpha=0,05)$. Diskusi: Kesimpulannya bahwa tapping therapy dapat menurunkan kadar glukosa darah pada pasien DM tipe 2 di Purwokerto. Penelitian ini menyarankan tapping therapy pada pasien dengan DM dilakukan paling sedikit satu kali sehari selama 30 menit.
\end{abstract}

Kata kunci: glukosa darah, diabetes, tapping therapy.

\begin{abstract}
Introduction: Diabetes Mellitus (DM) is a chronic metabolic disease that can lead to microvascular and macrovascular complications. This condition makes DM patients at higher risk of experiencing stress. Tapping Therapy is one of nursing intervention that can reduce stress. The purpose of this study was to identify the effect of tapping therapy on blood glucose levels in Primary Health Center South Purwokerto. Methods: This research was a quantitative with a quasi experimental with control group, recruited 30 respondents, consisted of 15 respondents who were trained on tapping therapy, one time daily for 30 minutes for four weeks and the other respondents were as the control group. The purposive sampling was used as the sample collection method. Wilcoxon test was employed to examine the differences of the mean of blood glucose levels between intervention and control groups. Results. The result revealed that there was a significant difference of blood glucose levels before and after treatment in intervention group $(p=0.003, \alpha=0.05)$. Discussion: The conclusion was that the tapping therapy can decrease blood glucose level on type 2 diabetes mellitus patients at Purwokerto. This research recommendation was to apply tapping therapy to patient with diabetes mellitus at least one time daily for 30 minute.
\end{abstract}

Keyword: blood glucose, diabetes, tapping therapy

\section{INTRODUCTION}

Diabetes Mellitus (DM) are called as silent killer disease (O'Hara, 2006). DM is a chronic metabolic disease that has no cure but it can be controlled with a healthy lifestyle and medication (Beever, 2005). DM is a multi systemic illness associated with a variety macrovascular and microvascular complications. Individuals with DM as likely to experience stress. Stress will trigger spending some hormones that contribute to increase blood glucose levels, the glucagon, epinephrine, growth hormone and glucocorticoid. Glucagon action againts insulin. Glucagon is the main hormone to raise glucose levels by stimulating glycogenolysis, lipolysis and gluconeogenesis. Epinephrine mobilizes reserves of glucose through glycogenolysis, the impact will increase will increase the circulation of free fatty acids. Growth hormone, reduce uptake of blood glucose by making the network, possibly through a reduction in the insulin receptor. The last is glucocortocoids, particularly cortisol, 
which will sustain the action of glucagon. In addition it will also reduce the use of glucagon by peripheral insulin, increases glycogenolysis and gluconeogenesis (Bullock and Henze, 2000). All of these factors tend to increase blood glucose levels so that patients requiring medical intervention and nursing intervention (Elliot \& Izzo, 2006).

One of the nursing interventions is complementary therapy. This therapy is a natural treatment to deal with the causes of disease and stimulate your own body to heal illness. Complementary therapies include herbal therapy, breathing exercises, meditation and relaxation ( $\mathrm{Xu}$ and $\mathrm{Yu}, 2004)$.

The tapping technique was first put forward by Gary Craig (1980). It has been found that the technique will setting tapping off energy system in the body, leading to the production of natural chemicals that affect the brain area appease the middle and existing systems. This allows the brain to the center of the opportunity to relearn existing associations related to the problem. This resulted in a state of self-regulation and balance naturally, so the impact on the balance of emotion and stress. If this is applied to the client with diabetes is expected that the client is able to control his emotions control so avoid the stress that can trigger an increase in blood sugar levels. Emotionally stable condition after DM tap treatment will help clients avoid the stress condition that increases blood sugar levels can be prevented.

Preliminary studies conducted in 2010 in South Navan, found the number of people with diabetes as much as 152 people. From previous research by Anam (2010) found about $65 \%$ of diabetic patients are depressed. Based on interviews with senior officers in one of the neighborhood health center of Navan Health Center South, the elderly who have diabetes and had received pharmacological treatment still experience up and down blood sugar. The therapeutic use non pharmacology or complementary therapies, such as tapping therapy on patient care in Navan DM South has not done. DM as a chronic metabolic disease can lead to stress and depression for the sufferer. Based on these phenomena, it is necessary to do research on the effect of tapping therapy on glycemic control in patients DM.

\section{METHODS}

This research was a quantitative study using a quasy-experimental with pre and post test control group design. This study was to identify the effect of tapping therapy on blood glucose levels. The number of sample were 30 respondents, consisted of 15 respondents on tapping therapy one time daily for 30 minutes for four weeks and 15 respondents as a control group. The purposive sampling was used as the sample collection method. The inclusion criteria were 1) type $2 \mathrm{DM}$ patients who have blood glucose levels $\geq 140 \mathrm{~mm} / \mathrm{dl}$, 2) cooperative 3) received oral diabetic agent, 4) willing to be proven by research respondents signed informed consent of research. Data were analyzed by a Wilcoxon test to examine the differences of the blood glucose levels before and after treatment.

\section{RESULT}

\section{Demographic Characteristics}

Table 1 showed the duration of diabetes. The mean duration of diabetes in control and intervention groups were similar 6 years. There were no significant differences of age between control and intervention group.

\section{Blood glucose levels}

Table 1 showed the increase of the mean blood glucose level before and after intervention in control group. While the decrease of the mean blood glucose level before and after intervention in intervention group. Therefore, table 4 showed there was a significant difference of blood glucose levels in intervention group. 
Effect of Tapping Therapy on Blood Glucose Levels in Type 2 (Atyanti Isworo, dkk.)

Table 1. Age and Duration of diabetes in Control and Intervention Group

\begin{tabular}{lccccccc}
\hline $\begin{array}{c}\text { Variable } \\
\text { Duration of Diabetes }\end{array}$ & Mean & Median & SD & Min-Max & n & $\mathbf{9 5 \% C I}$ & $\boldsymbol{p}$ value \\
\hline - Control Group & 6,13 & 6,0 & 3,461 & $2-15$ & 15 & $4,216-8,05$ & 0,949 \\
- Intervention Group & 6,33 & 6,0 & 3,415 & $2-15$ & 15 & $4,44-8,22$ & \\
\hline
\end{tabular}

Table 2. Blood Glucose Levels Before and After Intervention

\begin{tabular}{llcccccc}
\hline Variable & Group & Mean & Median & SD & Min-Max & n & $\boldsymbol{p}$ value \\
\hline Before & Control & 198,86 & 173 & 98,29 & $150-550$ & 15 & 0,826 \\
& Intervention & 284,8 & 298 & 64,54 & $159-377$ & 15 & \\
\hline \multirow{2}{*}{ After } & Control & 201,73 & 190 & 54,98 & $145-358$ & 15 & 0.510 \\
& Intervention & 227,33 & 222 & 62,98 & $116-347$ & 15 & \\
\hline
\end{tabular}

Table 3. The mean differences of Blood Glucose Levels

\begin{tabular}{llccc}
\hline \multicolumn{1}{c}{ Group } & N & Mean & Z Hitung & $\boldsymbol{p}$ value \\
\hline Control & 15 & 198,86 & $-1,677$ & 0,094 \\
Intervention & 15 & 284,8 & $-3,011$ & 0,003 \\
\hline
\end{tabular}

\section{DISCUSSION}

This study revealed that there were influences tapping therapy on blood glucose levels $(p=0,003)$. Tapping therapy is to balance energy in the body meredian system. Through balancing energy systems tapping therapy, this led to the production of natural chemicals that affect the brain area to relax. This allows of the center to relearn existing associations related to the problem. In turn this will lead to a state of self-regulation and balance naturally.

In patients with diabetes, as a result of hormonal imbalance often causes emotional instability, mental, and easy to feel anxious or stressed, this condition will also have an impact on the unstable blood glucose levels. Anxiety is a state of feeling apprehension, uncertainty or fear of the reality or perception of the actual source of the threat is unknown or known (Stuart and Sundeen, 2006). Anxiety is a condition characterized by a feeling of dread accompanied by signs stating the somatic nervous system, autonomic hyperactivity. Anxiety is a non-specific symptoms are common and often occur in people who normal. Source of anxiety is the fear of rejection among individuals that causes an individual to feel worthless, conflict in daily life and obsessions that are too high. Any changes in your life or life events can cause stress state will be preceded by the emergence of anxiety. Stress cause of physical and psychological impact, the narrowness of memory, difficulty concentrating and other negative impacts on the offensive (Keliat, 2006).

Due to a variety of negative thoughts and anxiety experienced by someone, often leading to an imbalance of energy in the body associated with repressed emotions or trapped in the human body system. When there is an imbalance, an integral amygdala sends information to the locus coeruleus which triggers the autonomic system and then transmitted to the hypothalamus resulting in the secretion of CRF. In relation to blood glucose levels, in response to CRF, issued the anterior pituitary adrenocorticotrophic hormone $(\mathrm{ACTH})$ in the blood, transported towards ACTH in the adrenal gland. ACTH stimulates cortisol production in the adrenal cortex. Cortisol is released in the blood stream, causing elevated levels of blood sugar, fatty acids and amino acids (Smeltzer \& Bare, 2008). Through therapy balancing the energy system with Tapping therapy, this causes the production of natural chemicals that affect 
the brain area to calm the central and existing systems. This allows of the center brain to relearn existing associations related to the problem. In turn this will lead to a state of selfregulation and balance naturally. Therefore the tapping therapy, cortisol will inhibit spending so there is no increase in blood glucose levels.

\section{CONCLUSION}

The conclusion was that the tapping therapy can decrease blood glucose level on type 2 diabetes mellitus patients at Purwokerto.

\section{RECOMMENDATION}

This research recommendation was to apply tapping therapy to patient with diabetes mellitus at least one time daily for 30 minute.

\section{REFERENCES}

Beever. (2005).New Type 2 Diabetes Cases Have Doubled in 30 Years: Health Reporter, http:////www.medicinet.com

Bullock and Henze. 2000. Nursing management of diabetes mellitus: Guide to the pattern approach. New York: Springer publishing company.

Elliot \& Izzo. 2006. New Type 2 Diabetes Cases Have Doubled in 30 Years: Health Reporter, http:////www.medicinet.com

Keliat, B.A. 2006. Manajemen stress.Jakarta: EGC

O'hara. 2006. Controlling Blood Glucose Through Relaxation Therapy. http:// www.diabetes.org/diabetesresearch/ summaries/mcginnis-biofeedbackRelaxation.jsp,

Smeltzer \& Bare, 2008. Brunner \&Suddarth's textbook of medical surgical nursing. Philadelpia: Lippincott.

Stuart \& Sundeen Psychiatric Nursing: Contemporary Practice. Philadelphia: Lippincott

Xu Yu. 2004. Relaxation on Diabetes Mellitus. Charlotte: University of North Carolina. http://www.psych.uncc.edu 